unable to refer it to any described species, and the form is therefore characterized as new.

Male. Length $1.5 \mathrm{~mm}$. Antennæ probably as long as the body, sparsely haired dark brown; 14 segments, the fifth with the stems, each with a length about twice the diameter; terminal segment missing. Palpi; first and second segments short, irregular, the third with a length about four times its diameter, the fourth $\frac{1}{4}$ longer than the third, the distal two thirds dilated. Mesonotum yellowish brown. Scutellum, post-scutellum and abdomen fuscous yellowish. Halteres yellowish basally, fuscous apically. Coxæ and femora basally yellowish, the distal portion of femora, tibia: and presumably tarsi, fuscous straw. Genitalia; basal clasp segment rather long, moderately stout and internally at the basal angle with a long, narrowly triangular lobe, the latter slightly curved apically; terminal clasp segment moderately long, slender; dorsal plate short, triangular, emarginate, the lobes broadly rounded; ventral plate short, broad, narrowly and irregularly rounded; style short, tapering to a narrowly rounded apex.

Female. Length $1.5 \mathrm{~mm}$. Antenna extending to the third abdominal segment, sparsely haired, fuscous yellowish; 14 segments, the fifth with a stem $\frac{1}{t}$ the length of the cylindric basal enlargement, which latter has a length $2 \frac{1}{2}$ times its diameter; terminal segment slightly produced, with a short, stout process apically. Palpi practically as in the male, except that the third and fourth segments appear to be nearly equal. Mesonotum purplish brown. Scutellum and post-scutellum yellowish brown; abdomen sparsely haired, deep red. Halteres yellowish basally, fuscous apically. Coxæ and femora basally yellowish, distal portion of femora, tibix and presumably tarsi, fuscous straw. Claws stout, strongly curved, bidentate, the pulvilli as long as the elaws. Ovipositor short, obtuse, the terminal lobes narrowly oval and sparsely setose. Type Cecid a2469.

This species presents a close general resemblance, both in antennal and alar characters, to Arthrocnodax from which it is most easily separated by the bidentate claws. The internal lobe of the basal clasp segment suggests a relationship to Coquillettomyia Felt, though there is no marked chitinization of the ventral plate or harpes so pronounced in this genus.

\title{
AMMONIA GAS AS A FUMIGANT
}

By D. E. FINk, Assistant, Truck Crop and Stored Product Insect Iniestigations, Burcau, of Entomology.

Ammonia has never been the subject of experiment as a fumigant so far as the writer can learn, at least in recent years. It first suggested possibilities in this direction when through accident the fumes were inbaled. Its properties as a disinfector add to its value, particularly when used on food products.

While the sources of ammonia are many, at the time the experiments were begun only one source was found available, viz., the "concentrated ammonia" obtained in drug stores, and said to contain 27 per cent of ammonia in solution. It is readily seen that in the use of this form it is necessary to handle practically three parts of water every time one part of ammonia gas is desired. 


\section{EXPERIMENT 1}

July 1, 1913, six quart bags containing cow peas previously sifted of all dead weevils and having only live weevils present were placed in a fumigation box of $8 \frac{2}{3}$ cubic feet capacity. Two ounces of concentrated ammonia were used.

July 2 , the results were as follows:

$\begin{array}{cccc} & \text { Dead } & \text { Alive } & \text { Per cent Killed } \\ 1 & 57 & 6 & 90 \\ 2 & 85 & 16 & 84 \\ 3 & 96 & 33 & \mathbf{7 4} \\ 4 & 66 & 9 & 88 \\ 5 & 9 & 7 & 56 \\ 6 & 81 & 39 & \mathbf{6 7}\end{array}$

EXPERIMENT 2

July 2, 1913, six quart bags of cow peas containing living weevils as in the previous experiment were subjected to 3 ounces of concentrated ammonia in the same fumigating box.

July 3 , the results were as follows:

$\begin{array}{cccc} & \text { Dead } & \text { Alive } & \text { Per cent Killed } \\ 1 & 42 & 0 & 100 \\ 2 & 61 & 0 & 100 \\ 3 & 74 & 1 & 99 \\ 4 & 64 & 0 & 100 \\ 5 & 52 & 0 & 100 \\ 6 & 25 & 0 & 100\end{array}$

Further experiments were undertaken with a 50-pound bag of cow peas which, with 3 ounces of the concentrated ammonia and an exposure of 48 hours, gave from 75 to 85 per cent of weevils killed. .

Experiments were tried with a 100-pound bag, the amount of concentrated ammonia being increased to 1 ounce to the cubic foot, but even this amount failed to give a high mortality. Further experiments with ammonia are under way to ascertain its value as a fumigant against household insects and stored product insects on a large scale.

\section{A NEW SPECIES OF KERMES FROM CONNECTICUT}

By Geo. B. King, Lawrence, Mass.

Kermes waldeni, n. sp. Adult female scale: Globular, $5 \mathrm{~mm}$. in diameter, shiny. Surface, yellowish brown, with four transverse very dark brown bands on the meson, and marbled with brown somewhat darker than the general surface color. Some of the marblings are circular. The surface is also marked with some dark brown dots, 